\title{
Saga do boi-bumbá em preto-e-branco
}

\section{Fátima Guedes*}

Resumo: O artigo propõe uma análise crítica do Festival Folclórico de Parintins considerando o contexto político, histórico e cultural em que se insere. Identifica as mudanças especialmente quando o boi sai da rua e vai para a arena. A partir daí define valores, estabelece limites e segrega o povo. A festa passou a ser construída de cima para baixo e o retorno para o caboclo vem como panacéias que não alcançam seus legítimos anseios.

Palavras-chave: Festival Folclórico, boi-bumbá, valores sociais e culturais.

Abstract: The article proposes a critical analysis of the Festival Folclórico de Parintins considering the political, historical and cultural context where it inseres itself. It identifies changes, especially when the boi leaves the street and goes to arena. Since then, it defines values, establishes limits and segregates people. The party became to be built from top to bottom and the gain to the caboclo comes as panaceas, which that don't reach their legitimate craving.

Keywords: Parintins Folk Festival, boi-bumbá, social and cultural valores.

$\mathrm{O}$ Festival Folclórico de Parintins tornou-se um mito e, como tal, necessita de uma análise crítica, tendo como parâmetro o contexto políticohistórico-cultural, para que ultrapasse os limites do ver, entre no mérito do julgar e, enfim, possa ser entendido, desvendado e direcionado no sentido de transformar-se em instrumento de educação e cultura.

Como todo mito, os bumbás utilizam-se de recursos conativos e efeitos alegóricos, que são reificados pela mídia, anestesiando assim a capacidade dialética no tocante ao discernimento entre falso e verdadeiro; realidade e fantasia.

\footnotetext{
* Licenciada em Letras, professora de Língua e Literatura Brasileira e diretora/proprietária da Oficina do Conhecimento "Fá - Tia Quente", em Parintins.
} 


\section{Fátima Guedes}

Há trinta e seis anos acompanhamos os passos da complicada trajetória dos bumbás de Parintins. Entre o ontem e o hoje, as distâncias acentuam-se e o horizonte torna-se enigmático. Não se trata de saudosismo, até porque acreditamos na história como "tempo de possibilidades", mas de compreender os mecanismos de intenções sobrepujando-se no processo de mudanças e, conforme Marx, aquilo que os homens haviam encarado como inalienável (arte, amor, ciência e consciência) tornou-se objeto de troca, de tráfico... e tudo passou a comércio.

\section{A ferra do boi}

O boi macula sua característica como boi popular quando sai da rua e é encurralado na arena. Com esse contexto, Parintins assimila, existencialmente, a condição de "vida de gado": povo ferrado, povo feliz. O caboclo que, antes, fazia e vivia o boi, tornou-se simples tarefeiro do boi e este se transformou em brinquedo de luxo para turista. A partir daí, o boi definiu valores, estabeleceu limites, privilegiou a elite e segregou a plebe. A estrutura passou a ser construída de cima para baixo e o retorno para o caboclo vem como panacéias que não alcançam as raízes dos legítimos anseios.

A quadra da Catedral de Parintins pode ser considerada como o terreiro de Nossa Senhora do Carmo, onde um público infanto-juvenil realiza seus folguedos e peladas. Foi nesta quadra, sob o olhar da Virgem do Carmo, que teve início o Festival Folclórico de Parintins, em 1965.

A princípio, a intenção da criação do festival partiu de um grupo de jovens católicos da JAC (Juventude Alegre Católica), que pretendia proporcionar lazer aos jovens através das manifestações folclóricas do município de Parintins: quadrilhas, pássaros, danças diversas e boi-bumbá. Por outro lado, a JAC era um instrumento de aglutinação de jovens para a Igreja Católica que, naquele momento, necessitava urgentemente assumir sua hegemonia, catolicizando o evento. Daí, surge o complicado paradoxo sacro-profano: Festival Folclórico e Festa da Padroeira, duas devoções que, no emaranhado do fanatismo, ao mesmo tempo, salvam e condenam.

Com o passar dos anos, o evento foi tomando corpo e forma, outros interesses (políticos e econômicos) foram a ele vinculados e a Igreja local perde o controle da situação para o governo municipal e, posteriormente, para o governo estadual.

Esse período de transição aconteceu de forma lenta e sutil, como todo processo invasor. Sem o controle da situação, a igreja de Parintins perde ter- 
reno e já não consegue gerenciar o festival e ampliar as “obras do Senhor” na Ilha Tupinambarana.

Na seqüência dos fatos, a Festa da Padroeira vem a reboque do Festival. A "Virgem do Carmo" tem que se contentar com as sobras da luxúria que lhes são permitidas, contrariando, assim, objetivos econômico-religiosos.

Considerando-se anunciadora dos "caminhos que levam à salvação" e do destino dos fiéis católicos, a Igreja, timidamente, reagia, criticando os exageros cometidos no Festival; porém, tais críticas não produziam ecos ou ressonâncias convincentes.

Surge um novo momento: o compositor Chico da Silva lança a toada "Boi do Carmo”. No jogo de palavras e arranjos estilísticos, o compositor aproxima as contradições: o profano e o sagrado misturam-se, confundem-se e, por ser “do Carmo”, a partir daí, tudo é permitido, tudo é artístico, tudo é cultural, tudo é folclórico.

O silêncio cumplicioso tem um preço: os bois assumem a decoração da festa, garantem a redução das despesas e, conseqüentemente, aumentam os lucros e, finalmente, “todos os pecados serão perdoados”.

Em termos alegóricos, é possível admitir que, no terreiro da Virgem do Carmo, a JAC pariu o boi-bumbá que envolveu o templo, o sagrado e, hoje, confunde a galera de beatos e beatas que navegam as águas agitadas do poluído mar vermelho e azul.

\section{Boi gordo $\mathrm{x}$ vacas magras}

A cidade de Parintins, através do Festival Folclórico, tateia no ilusionismo das nuanças, brincando de "Ilha da Alegria", "Cidade do Folclore”, etc., e, em nome do brilho, do grandioso, a ética humana cede lugar à ética do mercado e o vírus da globalização ensaia sutilmente mecanizar o belo, impondo normas de mercado. Assim, o Festival Folclórico ganhou proporções incalculáveis, chegando a pecar nos exageros e, como é peculiar do brasileiro, na tentativa de sufocar o preconceito colonialista e impressionar pelo volume de artifícios, o ufanismo leva os envolvidos até às últimas conseqüências. A luxúria, os interesses imperialistas, a orgia e o ufanismo cegam a criticidade, e a festa do boi assume a condição de credo: por ele se vive, por ele se morre e até se mata. 


\section{Fátima Guedes}

O novo modelo adotado pelo boi seduz e persuade, sob a alegação de que novos aditivos incorporados ao processo "trazem crescimento efetivo da economia para o município que só tem a ganhar e crescer".

Paralela a essa argumentação, é possível estabelecer parâmetros no tocante a perdas e ganhos para, enfim, diagnosticar até que ponto o Festival Folclórico está sendo promotor de educação, cultura e garantindo crescimento efetivo da economia e vida digna para todos.

Como base investigativa para o balanço que propomos, há pontos que merecem destaque:

No ritual dos exageros cometidos pelo festival, estão os mutilados do boi subvivendo no esquecimento sem qualquer garantia previdenciária; sem contar com os que perderam a vida, durante o traslado de alegorias faraônicas, desproporcionais para a infra-estrutura que a cidade oferece: precário sistema aéreo de fiação elétrica, vias de acesso inadequadas, ausência de área de concentração e desconhecimento de normas elementares de segurança no trabalho.

Outro ponto considerado delicado e emergente nesse processo é a questão "menores" (isca fácil e matéria-prima barata). Na organização do item "tribos", as agremiações, pelo que se tem de concreto, não desenvolveram, até agora, nenhum programa básico de caráter humanizante e, pela ausência de comprometimento com a causa, o "resgate" desses menores tornou-se uma prática rotineira e indispensável. Pelo que se sabe, através de contatos com esses menores, a grande maioria, advinda de famílias de baixa renda, é desprovida de leitura técnica e crítica da realidade, daí a isca para o "resgate" é o fator paixão pelo boi; assim, fica estabelecida a mão-de-obra infantil gratuita.

Durante os três dias de festa, tanto os organizadores de tribos como as famílias perdem o controle sobre esses menores que adentram pela noite, arriscam-se a toda sorte de mazelas e influências, alimentando o sonho de aparecerem na tela e/ou dar a vitória para o boi "querido".

O desfecho desse ritual tem induzido muitos menores ao consumo de drogas, ao homossexualismo e à prostituição; esta última tem oportunizado o surgimento de agenciadores de menores, conforme os dotes, para o turismo sexual na ilha, condenando nossas cunhãs ao desespero e, conforme o poeta, "na espera do milagre do arriamento, ficam tristes e, no rastro da tristeza, chegam à crueldade". 
Além do exposto, estatísticas sérias comprovam que o número de nascimentos durante os meses de fevereiro, março e abril, na grande maioria não tem paternidade reconhecida.

O Ministério Público, desarticulando esquemas, vem empreendendo incansável esforço no sentido de fazer valer o Estatuto da Criança e do Adolescente, porém, sem parcerias comprometidas, sem ações concretas por parte de outras instituições responsáveis, é possível parodiar o compositor Ronaldo Barbosa: a luta ainda "é um grito calado, que se embrenha no mato e se perde no ar".

Retomando a questão "tribos", é impossível omitir a prática idiotizadora contra a cultura indígena, através de macaqueações de rituais, crenças e mitos. Enquanto na arena aquele acervo milenar é mercadoria de luxo para "inglês ver", os protagonistas inspiradores do processo, estrangeiros no evento, definham lentamente nas artimanhas da invasão cultural, contaminados pelas mazelas da tal civilização. Durante a festa, há uma convergência massiva em torno do lúdico, do alegórico e das fantasias indígenas, como instrumentos de lascívia e erotização; porém, em se tratando do real, ninguém se arrisca, se quer provar do "pirão" daquela cultura.

No leilão das toadas defendidas pelos bumbás, prioriza-se a temática afinada com o discurso do equilíbrio ambiental. A concepção que adquirimos sobre a questão considera o homem como centro desse equilíbrio; porém, entre o que se pretende e o que se faz; entre o discurso e a prática, pertinentes no contexto, a questão é paradoxal. O lixo produzido pelos QGs, em proporção considerável, compromete a qualidade de vida do parintinense e fere os princípios mais elementares dispostos nas leis ambientais. No ápice da festa, na tentativa de elevar o clímax do enredo visual, queimam-se cargas e cargas de explosivos, cujos impactos comprometem a segurança dos moradores daquelas imediações e, conseqüentemente, o equilíbrio ambiental. O comprometimento com a questão permanece, por enquanto, no modismo do discurso.

Sempre se alimentou a crença de que as mudanças e transformações de uma sociedade passam, fundamentalmente, pelos objetivos educacionais trabalhados pela escola, numa concepção de que educação é processo de descoberta e definição de valores, segundo princípios éticos humanos. No real, a escola está para o boi como o luxo da festa está para a miséria do povo. Ao rufar dos primeiros tambores, o esvaziamento das salas de aula, principalmente do turno noturno, é notório. Infelizmente, o cardápio oferecido nos 


\section{Fátima Guedes}

programas escolares não combina com o momento, não estimula o "paladar" do educando, conforme os objetivos nacionais da educação: "visando o pleno desenvolvimento da pessoa, seu preparo para a cidadania e sua qualificação para o trabalho"; enfim, não oferece mecanismos de interação entre as partes para uma possível definição do festival como caminho de humanização.

Daí, o velho "bê-á-bá" vai caducando, tropeçando na importação de modelos e distanciando-se, cada vez mais, da realidade, dos anseios, das utopias e da curiosidade do educando.

Os fatos e acontecimentos que se desenvolvem em Parintins estão conectados entre si e são palpáveis à criticidade dos que se envolvem como agentes da história. Observando o processo por esse parâmetro, o Festival Folclórico vem favorecendo a cumplicidade dos sistemas instalados na Ilha. A saúde, por exemplo: é comum, durante os três dias da festa, a convergência de forças governistas do Município e do Estado, no tocante à implantação de um verdadeiro mutirão, que vai de simples ações emergenciais a atendimentos mais específicos; porém, passado o momento do boi, o caos se reifica e o parintinense é condenado a madrugar nas calçadas dos postos e hospitais, na mendicância de uma ficha para um utópico atendimento e, paralelamente, todo um sistema volta à estaca zero, começando pela falta de medicamentos até para simples socorros emergenciais; enquanto isso, milhares de reais são transformados, em questão de horas, em lixo, cinzas e fumaça.

Passa o boi e, para o parintinense viciado à condição de paciente da história, sobram as fantasias palanqueavélicas, no aguardo de próximos eventos.

\section{Para além da carne-seca}

Até onde a visão permitiu a leitura da saga do boi-bumbá de Parintins, é possível afirmar que, conforme a ética universal humana, as perdas vão além do anunciado; para a ética do mercado, o "crescimento efetivo da economia" necessita de ousadia no gerenciamento, e de projetos mais audaciosos para garantir auto-sustentação e independência.

Após esta dura e complicada viagem e enigmática visão do futuro, já é possível, nesse momento, divisar na infinitude do horizonte "bandeiras audaciosas”, apontando nítidos sinais e acenando novos tempos.

A trajetória política de Parintins, ao longo do tempo, segue o mesmo padrão de outras províncias brasileiras; porque não dizer que o tradicional "coronelismo”, de cara nova, instalou-se na Ilha e não demonstra nenhum interesse 
em abandonar o filé, comprovando que tudo está conectado à cadeia de fatos e acontecimentos que determinam a história; em se tratando de Parintins, com base na retrospectiva histórica que se tem, a operacionalização dos sistemas (educação, saúde, urbanização, segurança, etc), não poderia ser diferente dos modelos imposto por seus idealizadores. A única exceção é o Festival Folclórico, por ser peça fundamental do aparelho ideológico.

Apesar da ausência de guerra a essas contradições da Ilha, o parintinense é um povo cansado; cansado de esperar que as coisas mudem de rumo, a partir de projetos e promessas caducas anunciadas no Município por várias décadas. Hoje, a descrença na política e nas instituições, como gerenciadoras de mudanças, toma conta dos ilhéus que, remota e acanhadamente, profetizam a salvação do Município através do boi.

No início deste tópico, falávamos em nítidos sinais na linha do horizonte. Realmente, já existem intenções apontando para a democratização e, conseqüentemente, para a humanização de alguns setores dos bumbás, reaproximando-os, assim, dos anseios da comunidade. Também já é nítida a intenção de transformar o boi numa empresa séria, lucrativa (por que não sonhar?) e braço direito da economia do município.

Como parte dos sonhos, as escolas de arte dos bumbás podem representar sinais de novos tempos, a partir do momento em que, em seus reais objetivos, conceba-se a arte como expressão da vida e que esta possa manifestarse além dos limites do comércio.

Ainda, nas fantasias da saga do boi, há uma corrente muito forte de intenções na tentativa de transformar Parintins num pólo de desenvolvimento turístico sustentável. É sabido que turismo sustentável necessita de infra-estrutura adequada e compatível com as exigências do turista. Dentre outras exigências, são prioridades: paisagem natural, meio ambiente equilibrado, alternativa de lazer, serviço completo e eficiente de hospedagem, segurança, diversificação e inovação de produtos comerciais, etc.

No momento, tais prioridades encontram-se em estágio incipiente; até o que resta de paisagem natural pede socorro; portanto, sobram os bumbás como atração, até única, para tirar Parintins da solidão e do isolamento. Os sonhos com o turismo, porém, são audaciosos; vêm sendo alimentados em doses homeopáticas e, quem sabe, a longo prazo, Parintins entre realmente em movimento ascendente, eliminando a nadificação e, enfim, o turismo seja uma ponte para o futuro. 


\section{Fátima Guedes}

Para alguns (compositores, artistas plásticos, músicos, dançarinos, etc.), o boi representa um espaço, talvez o único, para acreditarem-se gente, nem que o seja por um dia. A questão nos faz lembrar Eduardo Áureo dos Santos, o saudoso e popular Engole Cobra, personagem desta ilha, alvo de muitas lendas e ferrenho torcedor do Garantido.

Certa vez, aquele cidadão desabafou: "durante o ano todo, nesta ilha, sou bicho. Sou macaco, sou peixe, sou porco e sou cavalo. Sou macaco, quando empresto minha coragem para cortar galhos de árvores, próximos a fios de alta tensão; sou peixe, quando desafio os mistérios do rio, para retirar do fundo embarcações que vão a pique; sou porco, quando me usam para limpar fossas estouradas e, finalmente, sou cavalo quando, por alguns trocados, empresto meus ombros para transportar cargas e encomendas". Prosseguiu: "o único dia em que sou gente é o dia 30 de junho, quando me enfeito para sair no Garantido”.

Realmente, a rotina e a mesmice da Ilha têm contribuído muito para a proliferação de bichos humanos que, por não terem opções, encontram nas cores dos bumbás uma razão superior para acreditarem-se Gente, nem que seja por um dia ou por algumas horas da noite, cujo sonho termina com as primeiras luzes da manhã, desvendando a realidade.

Sabe-se que a marcha da história é antiga, a trajetória é complicada e a saga do boi necessita urgentemente de que as bandeiras rubro-azuis, que acenam para o horizonte, sejam capazes de descortinar a realidade parintinense, entender que o acervo bumbalino, como perspectiva de mudanças e transformações nas esferas social, política, econômica e cultural, vai além do azul, do vermelho, dos três dias do festival, e que a história do boi é tempo de possibilidades e utopias...

E assim, quem sabe, "após missa na matriz/nosso povo seja feliz.../salve, irmãos!/salve irmãs!”.

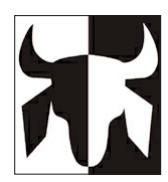

